Original Research Paper

\title{
Time-Temperature Dependency of Laminated Glass Subjected to Blast Load - A Numerical Study
}

\author{
Matthias Förch \\ HafenCity University Hamburg, Professorship for Façade Systems and Building Envelopes, Hamburg, Germany
}

\section{Article history}

Received: 26-01-2020

Revised: $15-02-2020$

Accepted: 16-03-2020

Corresponding Author:

Matthias Förch

Werner Sobek Hamburg,

Germany

Email: matthias.foerch@wernersobek.com

\begin{abstract}
The behavior of laminated glass has strong time-temperature dependency. Viscoelastic material models are often employed to define mechanical properties of Polyvinyl Butyral (PVB), the most common interlayer for structural glass applications. However, it is an apparent notion to simplify the high complexity of such material models, as only specific software is capable of considering this behavior. Most studies in blast design of laminated glass have focused on room temperature condition and recommend the use of elastic material models for PVB with high modulus of elasticity for simplification. The main purpose of this study is to develop an understanding of time and temperature dependency of interlayers in real building application. On the basis of empirical weather data, a range of interlayer temperatures is proposed to be considered for blast design situation in Germany for vertical double glazed and triple glazed units in accordance with Eurocode 0 and Eurocode 1. The results obtained from this analysis are further investigated within a transient structural parametric study of laminated glass to identify the effect of winter interlayer temperature and summer interlayer temperature in difference to simplified monolithic glass approach. As a result, significant increase of maximum principal glass stress and maximum deformation is observed for laminated glass subjected to blast load under summer temperature condition.
\end{abstract}

Keywords: Laminated Glass, Time-Temperature Dependency, Interlayer, Blast Load, PVB

\section{Introduction}

Time and temperature dependency of interlayers from short load duration (wind load, barrier load) to permanent load duration (dead load) are examined in a wide variety of publications, e.g. Vallabhan et al. (1993), Van Duser et al. (1999), Kutterer (2003), Schuler (2003), Wellershoff (2006) and Sackmann (2008). In difference, only few publications exist for laminated glass subjected to blast load. Here, different interlayer material models for FEA are described for laminated glass subjected to blast load prior to fracture in literature. Kolling et al. (2012) suggest to apply monolithic shell elements or solid elements instead of laminated glass for impact or blast load for simplification. Wei and Dharani (2005), Hooper (2001), Del Linz (2014) and Kuntsche (2015) compare viscoelastic material models with linear elastic material models, concluding that the linear elastic approach of Polyvinyl Butyral (PVB) in laminated glass is sufficient for typical blast loads. Employed moduli of elasticity for linear elastic material models of PVB interlayers of mentioned literature are in a range between $282 \mathrm{~N} / \mathrm{mm}^{2}$ and $70,000 \mathrm{~N} / \mathrm{mm}^{2}$ while the authors are focused on room temperature conditions. Furthermore, two references investigate the behavior of laminated glass plates subjected to blast and temperature load. Makki et al. (2015) ran experimental shock tube tests with coated laminated glass plates $(0.279 \mathrm{~mm}$ chemical adhesive bond $-3.14 \mathrm{~mm}$ glass $0.76 \mathrm{~mm}$ PVB - $3.14 \mathrm{~mm}$ glass - $0.279 \mathrm{~mm}$ chemical adhesive bond) at temperatures $-10^{\circ} \mathrm{C}, 0^{\circ} \mathrm{C}, 25^{\circ} \mathrm{C}, 50^{\circ} \mathrm{C}$, $80^{\circ} \mathrm{C}$ and $110^{\circ} \mathrm{C}$. Here, increasing deflection and in-plane strain with increasing temperature due to the temperaturedependent material properties of the chemical adhesive bond and PVB interlayer is observed. Bermbach et al. (2016) conducted experimental investigations with focus on postfracture behavior of different laminates at $13^{\circ} \mathrm{C}$ and $30^{\circ} \mathrm{C}$ concluding that the influence of temperature is significant, as it may triple average strain rates for the same blast loading.

This article presents detailed investigation of timetemperature dependency of laminated glass subjected to blast load. First, a brief introduction to the mechanical behavior of interlayers is provided, showing that the mechanical behavior of interlayer materials strongly depends on interlayer temperature and shear relaxation time. 
Second, the design temperature of interlayer in blast design situation for vertical double glazed and triple glazed units is determined for Germany. Therefore, empirical weather data for a 50 year period are surveyed and used for thermal calculation, in order to define a design interlayer temperature range for blast design situation according to DIN EN 1990 (2010).

Third, laminated glass plates subjected to common idealized blast loads are analyzed under the proposed maximum and minimum interlayer temperature condition by transient FEA. Idealized blast loads, interlayer materials and plate widths are varied in this parametric study. Although only analyzing one glass thickness and plate ratio, significant increase in maximum principal glass stress and maximum deformation is observed especially for summer temperature condition.

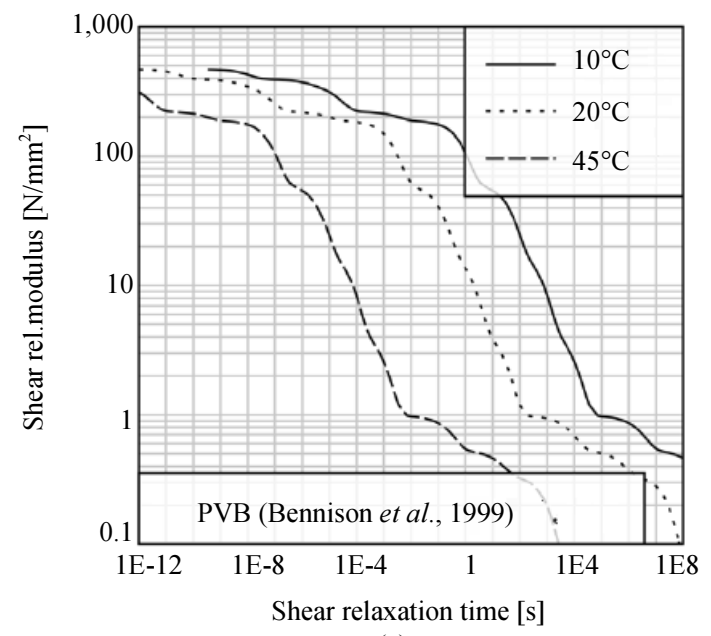

(a)

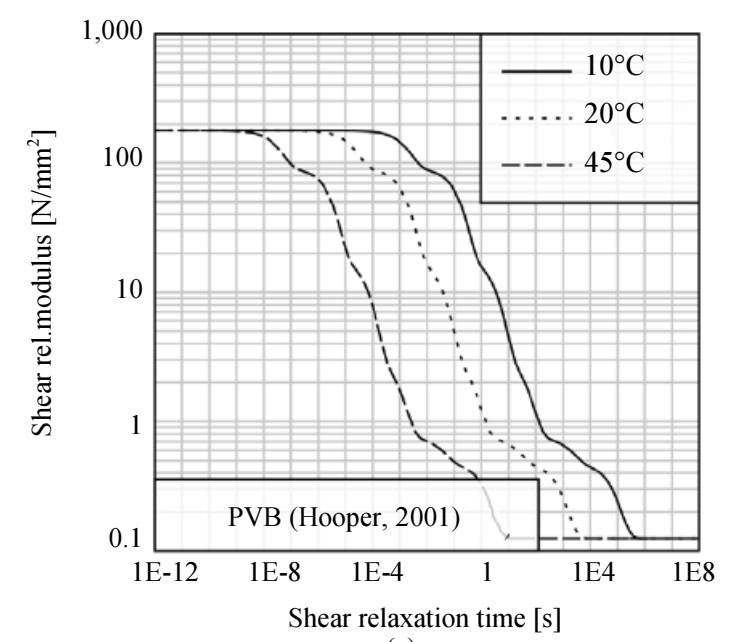

(c)

\section{Time-Temperature Interlayer Dependency}

In order to determine the viscoelastic mechanical properties of interlayers, various testing methods on single interlayer specimens can be used, e.g., Dynamic Mechanical Analysis (DMA) or uniaxial tension testing. As a result, generalized Maxwell models can be obtained, that are capable of specifying the shear relaxation behavior for a reference temperature, depending on shear relaxation time. In combination with temperature shift functions, e.g. Williams-Landel-Ferry (WLF) equation, temperature dependency can be considered in addition. Figure 1 incorporates shear relaxation curves of 4 different interlayer products at different temperature conditions. It is obvious, that time and temperature are important influencing parameters for shear relaxation moduli.

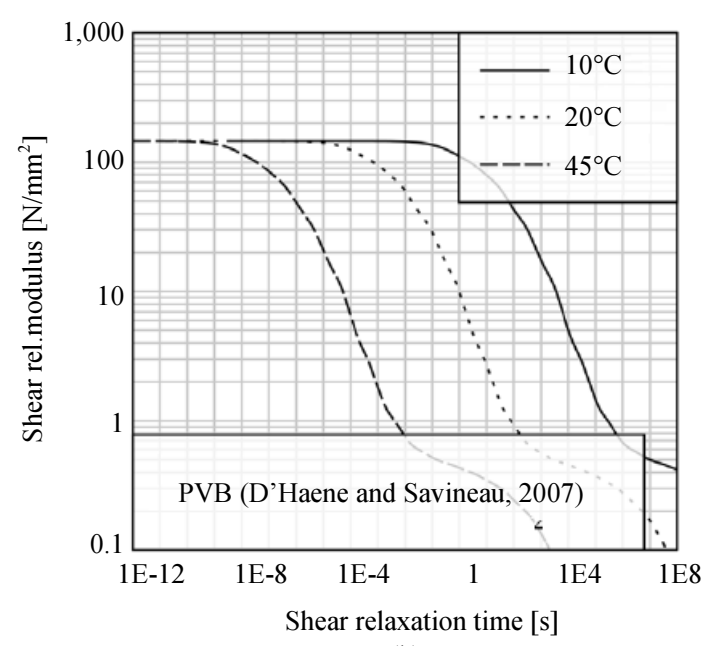

(b)

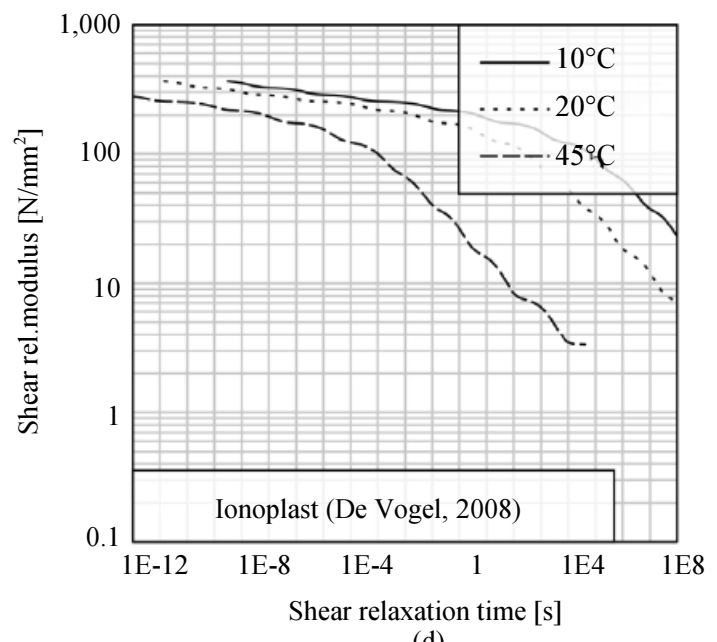

(d)

Fig. 1: Shear relaxation curves according to generalized Maxwell models. (a) Bennison et al. (1999). (b) D'Haene and Savineau (2007). (c) Hooper (2001). (d) De Vogel (2008) 


\section{Design Interlayer Temperature in DGU and TGU}

The present study focuses on the determination of a temperature range for interlayers in typical vertical Double Glazed Units (DGU) and Triple Glazed Units (TGU) for Germany regardless of orientation. As a result, a minimum and maximum interlayer temperature is proposed for use in the combination of actions for blast design according to Eurocode 0 as variable action. Two thermal combinations are considered as summer combination (maximum interlayer temperature) and winter combination (minimum interlayer temperature). The investigations are based on empirical weather data and refer to glass units with laminated glass to the indoor side, because this is usually regarded as a minimum requirement for blast enhanced glazing.

\section{Outdoor Air Temperature}

For verified statistical assessment, hourly data from 7 weather stations in Germany (Table 1 and Fig. 2) by Deutscher Wetterdienst (2014) are used for evaluation of outdoor air temperatures for a 50 year period. This corresponds to the requested annual exceedance probability value of 0.02 according to DIN EN 1991- 1-5 (2010). Table 1 presents evaluated values from raw data as basis for thermal calculation.

\section{Operative Room Temperature}

Operative room temperature mainly depends on outdoor air temperature and occupancy type. DIN EN 15251 (2012) specifies criteria for indoor environmental parameters of buildings, focused on building category II, which is recommended for new and renovated buildings. Figure 3 shows the operative indoor comfort and tolerance temperature of housing and office occupancy. However, blast endangered occupancies with lower winter operation temperatures like corridor areas, museums or stores are also covered subsequently. Therefore a minimum tolerable indoor operative room temperature for building category II in winter period of $16^{\circ} \mathrm{C}$ is considered (DIN EN 152512012 ). In conclusion, two operative room temperatures are considered for the examined thermal calculation: $26^{\circ} \mathrm{C}$ for summer combination (maximum interlayer temperature) and $16^{\circ} \mathrm{C}$ for winter combination (minimum interlayer temperature).

\section{Radiation}

Radiation energy exchange between surfaces and surrounding air depends on global radiation and thermal radiation of the atmosphere. Global radiation generated by the sun on a surface, having short wave lengths between $300 \mathrm{~nm}$ and 4,000 nm (VDI 3789 Part3, 2001), is the sum of direct beam, sky diffuse and in case of inclined surface ground reflected radiation. Thermal radiation of the atmosphere (between surface and sky), having long wave lengths greater than $4,000 \mathrm{~nm}$, appears from a surface as thermal radiation from the body and backwards on a surface as downwardly directed thermal radiation of atmospheric gases and clouds. Generally, the influence of thermal radiation of the atmosphere compared to global radiation is rather small. In addition, thermal radiation of the atmosphere is less critical for (vertical) facades compared to horizontal surfaces, so this effect is not taken into account for further investigations.

For verified statistical assessment, hourly data for global radiation from the same 7 weather stations as for outside air temperature determination, provided by Deutscher Wetterdienst (2014), are used for a 50 year period. The raw data, including hourly sum of global radiation and diffuse radiation for horizontal surface, are used to determine the values in Table 2. In general, solar radiation is measured only for horizontal surface by most weather stations, as inclined surfaces would require multiple measurements in various orientations, having the disadvantage of local influences as ground reflection and horizon obstructions. However, estimations for inclined surface global radiation exist in Palz and Greif (1996) for daily and monthly mean values at various European sites, as this research is mainly focused on photovoltaics or solar heating, where daily or monthly mean values are sufficient. The present study requires hourly mean radiation values for inclined surfaces which are not available in the literature. As a consequence, conversion from horizontal to vertical surface is required, to obtain solar radiation values for (vertical) facades.

In Förch (2019), an estimation of hourly mean global radiation values for vertical surface without limitation of the horizon is developed, incorporating the values of Deutscher Wetterdienst (2014). This estimation is based on VDI 3789 Part2 (1994) which is focused on hourly mean values. Result of the estimation is that the sum of direct beam, sky diffuse and surface ground reflected radiation has a maximum value of 1,626 $\mathrm{W} / \mathrm{m}^{2}$ for vertical surface (at a solar altitude angle $\gamma=$ $10^{\circ}$ ). Hence, a maximum value of direct beam, sky diffuse and surface ground reflected radiation of 1,700 $\mathrm{W} / \mathrm{m}^{2}$ is used for vertical facades for further investigations on the safe side.

\section{Combination of Actions}

The combination of actions for accidental design situations is defined as (DIN EN 1990 2010):

$$
\begin{aligned}
& E_{d}=\sum_{j \geq 1} G_{k, j}{ }^{++"} P_{"+"} A_{d "+"}\left(\psi_{1,1} \text { or } \psi_{2,1}\right) Q_{k, 1} \text { "+" } \\
& \sum_{i \geq 1} \psi_{2, i} Q_{k, i}
\end{aligned}
$$


$E_{d}$ is the design value of effect of actions, $G_{k, j}$ is characteristic value of permanent action, $P$ is relevant representative value of a prestressing action, $A_{d}$ is design value of accidental action, $Q_{k, i}$ is characteristic value of variable action, $\psi_{1}$ is a frequent value of a variable action and $\psi_{2}$ is a quasi-permanent value of a variable action. Two limiting combinations of actions, based on Equation (1), are proposed to determine the combination of actions for bomb blast action on glass plates: Summer combination for maximum interlayer temperature and winter combination for minimum interlayer temperature.

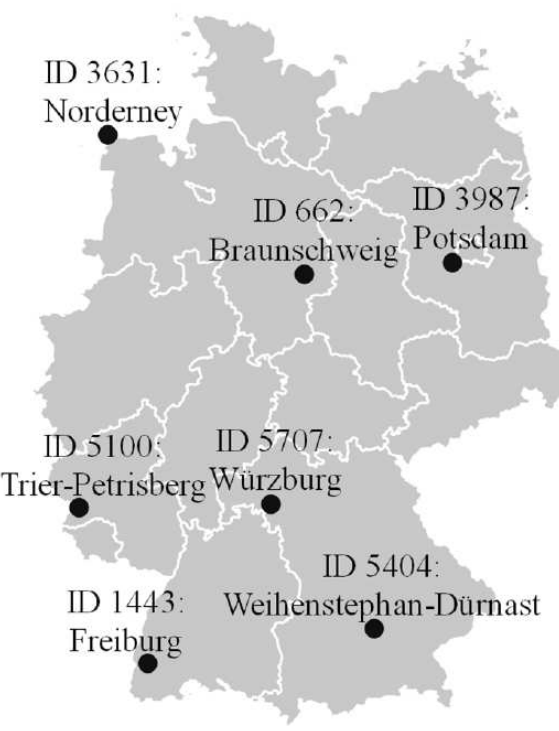

(a)

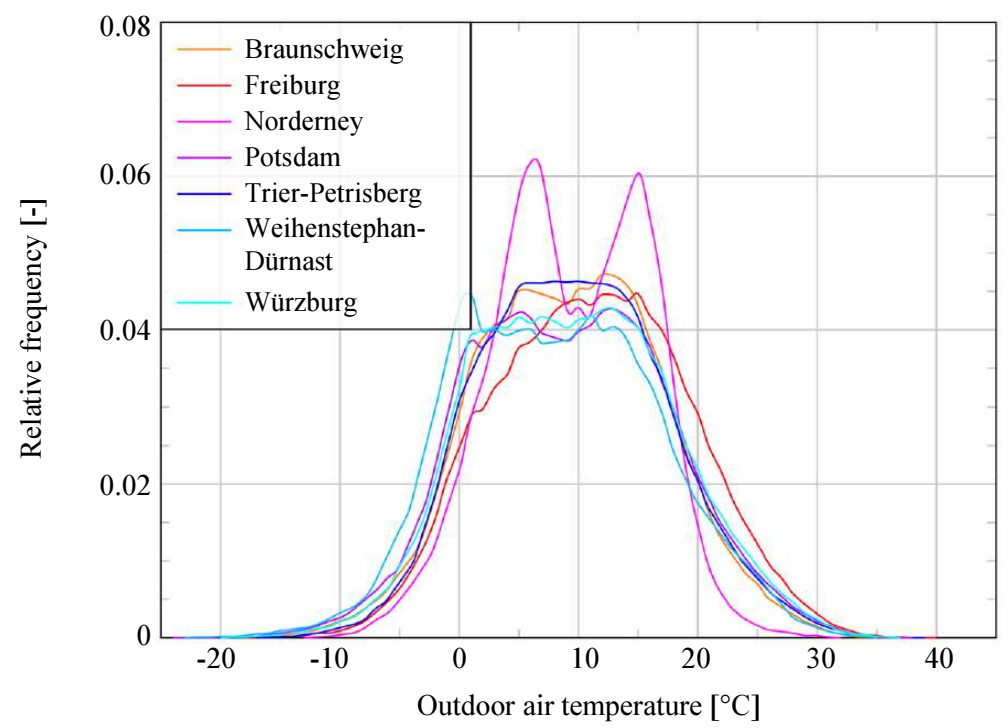

(b)

Fig. 2: (a) Weather stations used for investigations (C GeoBasis-DE/BKG, 2018, modified data). (b) Relative frequency of hourly mean outdoor air temperatures evaluated from Deutscher Wetterdienst (2014). Corresponding chart to Table 1

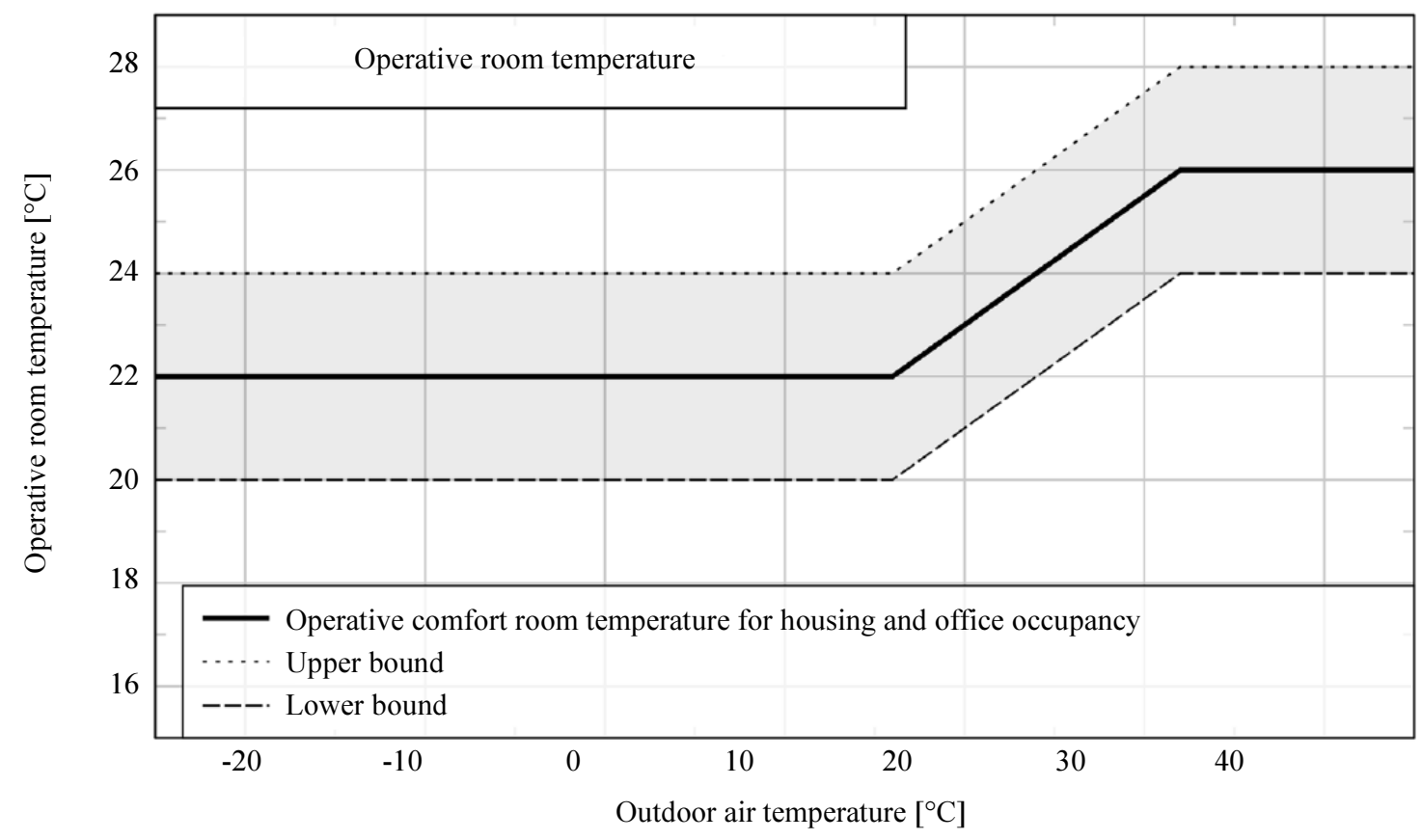

Fig. 3: Operative room temperature and tolerance area for housing and office occupancy depending on hourly mean outdoor air temperature according to DIN EN 15251 (2012) 
Table 1: Hourly minimum, maximum and mean outdoor air temperature values evaluated from Deutscher Wetterdienst (2014)

\begin{tabular}{llllllll}
\hline Location & Station ID & Min. temp. & Max. temp. & Mean temp. & Period until & Datasets & Missing data \\
\hline$[-]$ & {$[-]$} & {$\left[{ }^{\circ} \mathrm{C}\right]$} & {$\left[{ }^{\circ} \mathrm{C}\right]$} & {$\left[{ }^{\circ} \mathrm{C}\right]$} & $31 / 12 / 2013$ [years] & {$[$ [no.] } & {$[\%]$} \\
\hline Braunschweig & 662 & -22.0 & 37.3 & 9.3 & 50 & 438,294 & - \\
Freiburg & 1443 & -18.5 & 39.6 & 11.0 & 50 & 438,171 & - \\
Norderney & 3631 & -13.9 & 33.4 & 9.4 & 50 & 438,316 & 0.002 \\
Potsdam & 3987 & -24.4 & 38.6 & 9.1 & 50 & 438,311 & - \\
Trier-Petrisberg & 5100 & -18.1 & 38.5 & 9.5 & 50 & 438,260 & - \\
Weihenstephan-Dürnast & 5404 & -23.1 & 35.9 & 8.0 & 18 & 156,268 & 0.001 \\
Würzburg & 5705 & -21.2 & 37.2 & 9.4 & 50 & 438,303 & - \\
\hline
\end{tabular}

Table 2: Maximum hourly mean global and maximum hourly mean diffuse radiation values on horizontal surface with corresponding missing data evaluated from Deutscher Wetterdienst (2014)

\begin{tabular}{|c|c|c|c|c|c|c|c|c|}
\hline Location & $\begin{array}{l}\text { Station } \\
\text { ID }\end{array}$ & $\begin{array}{l}\text { Max. } \\
\text { global rad. }\end{array}$ & $\begin{array}{l}\text { Miss. } \\
\text { data }\end{array}$ & $\begin{array}{l}\text { Max. } \\
\text { diffuse rad. }\end{array}$ & $\begin{array}{l}\text { Miss. } \\
\text { data }\end{array}$ & $\begin{array}{l}\text { Period until } \\
31 / 12 / 2013\end{array}$ & $\begin{array}{l}\text { Datasets incl. } \\
\text { miss. data }\end{array}$ & $\begin{array}{l}\text { Max. Solar } \\
\text { altitude angle }\end{array}$ \\
\hline$[-]$ & {$[-]$} & {$\left[\mathrm{W} / \mathrm{m}^{2}\right]$} & {$[\%]$} & {$\left[\mathrm{W} / \mathrm{m}^{2}\right]$} & {$[\%]$} & [years] & [no.] & {$\left[{ }^{\circ}\right]$} \\
\hline Braunschweig & 662 & 994 & 0.1 & 847 & 14.8 & 50 & 439,703 & 60.6 \\
\hline Freiburg & 1443 & 1,072 & 3.5 & 675 & 10.5 & 41 & 350,639 & 64.7 \\
\hline Norderney & 3631 & 1,044 & 3.1 & 822 & 14.7 & 50 & 439,728 & 59.2 \\
\hline Potsdam & 3987 & 994 & 0.1 & 700 & 0.2 & 50 & 438,311 & 60.5 \\
\hline Trier-Petrisberg & 5100 & 1,039 & 1.3 & 694 & 17.0 & 50 & 433,920 & 63.1 \\
\hline Weihenstephan-Dürnast & 5404 & 1,039 & 1.2 & 828 & 12.3 & 50 & 438,312 & 64.4 \\
\hline Würzburg & 5705 & 1,053 & 0.1 & 817 & 14.8 & 50 & 438,312 & 63.0 \\
\hline
\end{tabular}

For summer combination, maximum outdoor air temperature situation and maximum global radiation are used as one variable action $Q_{k, 1}$, as high outdoor air temperature and high global radiation value may occur at the same time. For winter combination, only minimum outdoor air temperature situation without global radiation is used. Table 3 summarizes the proposed combinations of actions for bomb blast design situation.

The proposed approach of using maximum values for a 50 year period is a straightforward method, being not identical from mathematical perspective with the procedure in Eurocode 0, considering annual extreme values with a return period of 50 years (Gulvanessian et al., 2012). A comparison with regard to outdoor air temperature shows that the differences are rather small $\left(-24^{\circ} \mathrm{C}\right.$ and $+37^{\circ} \mathrm{C}$ according to DIN EN 1991-1-5/NA (2010)). For outdoor air temperature, a frequent value of variable action $\psi_{1,1}=0.5$ (DIN EN 1990, 2010) is used. This value is also employed for global radiation action, which is supported by DIN EN 1991-1-5 (2010). The national annexes DIN EN 1990/NA (2010) and DIN EN 1990/NA/A1 (2012) confirm this procedure. The characteristic value of $\psi_{1,1} Q_{k, 1}$ for outdoor air temperature is proposed as mean temperature \pm the difference temperature between maximum or minimum temperature and mean temperature multiplied by $\psi_{1,1}$ for each of the 7 weather stations used for investigation. This assumption is based on temperature actions for bridges according to DIN EN 1991-1-5 (2010). Operative room temperatures are used according to Fig. 3. In summary, the design values presented in Table 4 are used for variable action in steady-state thermal calculation.

\section{Thermal Calculation of Typical DGU and TGU of Facades}

In order to achieve the minimum and maximum interlayer temperatures, a thermal calculation study is done. Therefore, DGU and TGU with minimum glass layer thickness $(4 \mathrm{~mm})$ and maximum glass layer thickness $(12 \mathrm{~mm})$ are used in combination with clear glass products with typical positions of low-e coating and without solar control coating, frit or shading device. Radiant temperatures are assumed to have the same values as air temperatures. Result of the calculations is shown in Fig. 4. Here, the interlayer temperature of typical double and triple glazed units of facades is between $13.1^{\circ} \mathrm{C}$ and $42.8^{\circ} \mathrm{C}$. Therefore, two interlayer temperatures are proposed to be considered for bomb blast action in Germany: $10^{\circ} \mathrm{C}$ for minimum design interlayer temperature in blast design situation and $45^{\circ} \mathrm{C}$ for maximum design interlayer temperature in blast design situation. Detailed calculation results are presented in Table 5. Glass systems differing from Fig. 4 can result in higher temperature ranges for interlayers.

The calculations are done with the software WIS (Van Dijk et al., 2006), which is a European software for 2-dimensional numerical heat transfer calculations of window systems using a finite difference method. Basis of the calculation is DIN EN 673 (2011) and DIN EN 410 (2011). Heat transfer resistance values presented in Table 6 are used in accordance with DIN EN 673 (2011) and DIN EN ISO 6946 (2008). As the difference of internal heat transfer resistance between both standards is rather small in the present case, $R_{s i}=0.13 \mathrm{~m}^{2} \mathrm{~K} / \mathrm{W}$ is used for calculation. To obtain the minimum interlayer temperature for winter combination, the external heat transfer resistance $R_{s e}=0.04 \mathrm{~m}^{2} \mathrm{~K} / \mathrm{W}$ is used, whereas to obtain the maximum interlayer temperature for summer combination, the external heat transfer resistance $R_{s e}=$ $0.11 \mathrm{~m}^{2} \mathrm{~K} / \mathrm{W}$ is employed for calculation. A normal emissivity of $\varepsilon_{n}=0.03$ (measured value according to DIN EN 12898 (2001)) for low-e coating is used, which 
can be transformed into a corrected emissivity of $\varepsilon=$ 0.037 (DIN EN 12898, 2001). Spectral data of glass products used for calculations are provided by Häuser (2014) and implemented into the software. Float $4 \mathrm{~mm}$ and $12 \mathrm{~mm}$ without low-e coating (product name

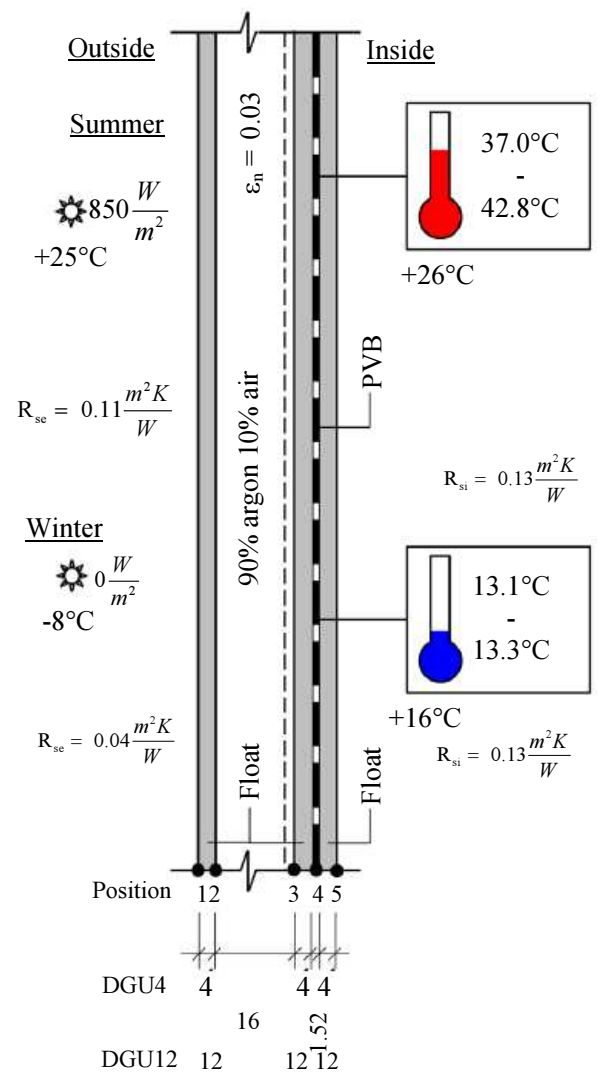

(a)
Planibel) and with low-e coating (product name Iplus Top 1.1) is used. Spectral data are shown in Fig. 5 and 6. Furthermore, a solar spectrum for the relative optical air mass $m\left(90^{\circ}\right)=1$ is used, which is in accordance with the mentioned standards.

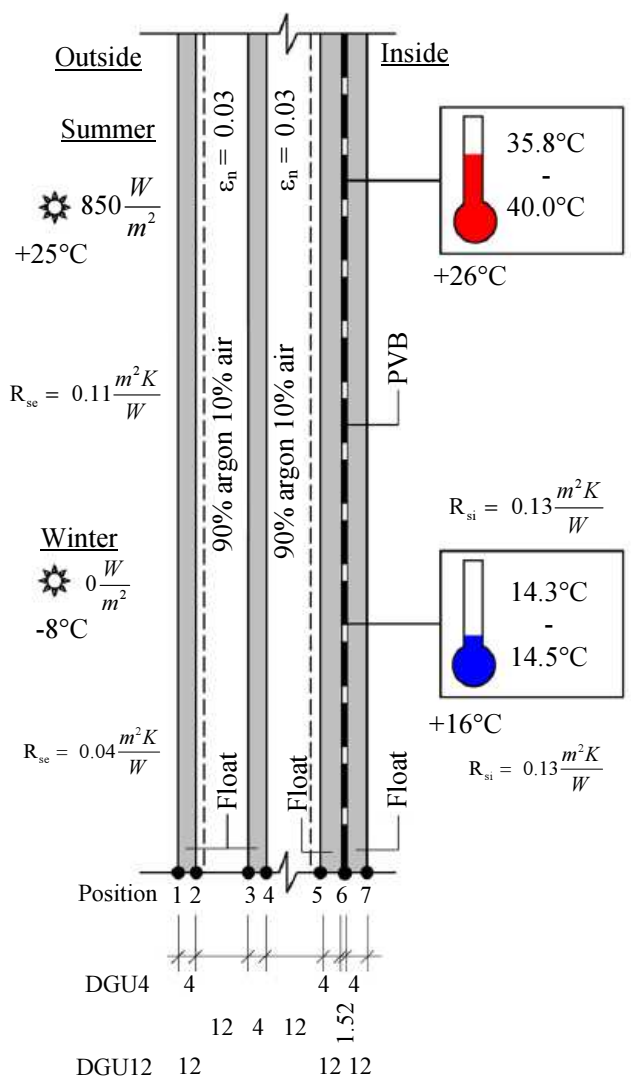

(b)

Fig. 4: Glass build-up, actions and result of thermal calculations. (a) Double Glazed Unit (DGU). (b) Triple Glazed Unit (TGU)

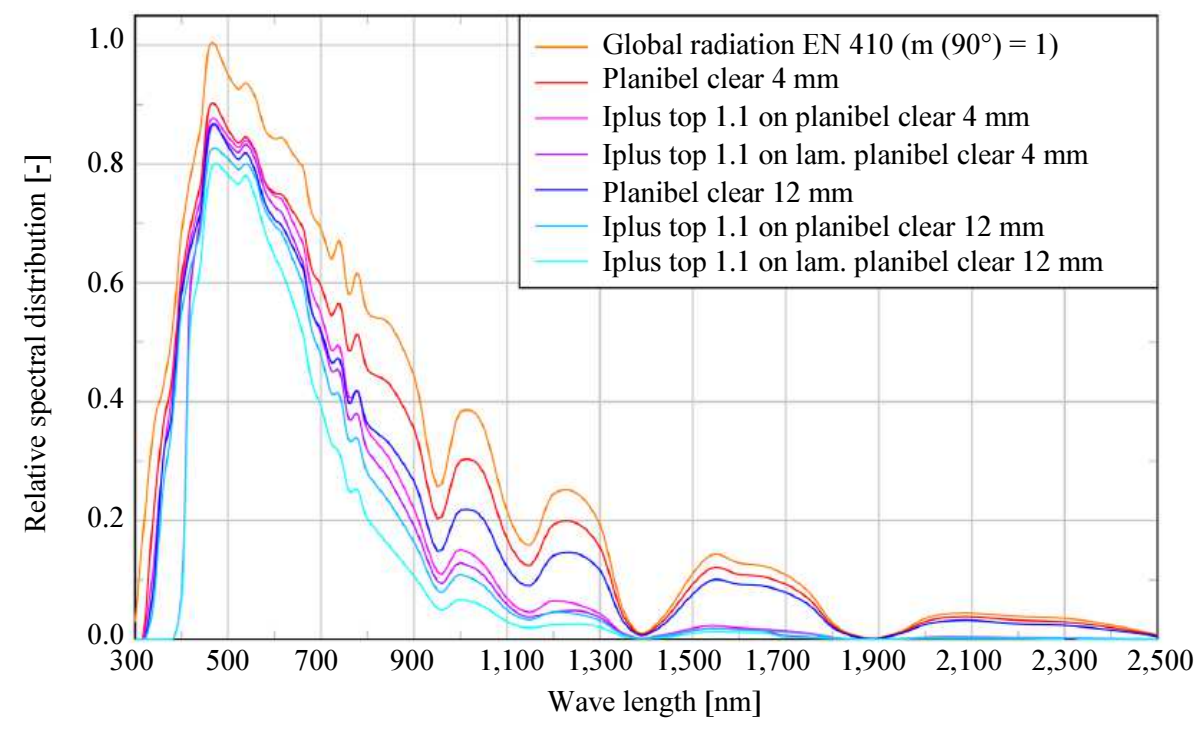

Fig. 5: Solar transmittance of different glass plates by Interpane (Häuser, 2014) 


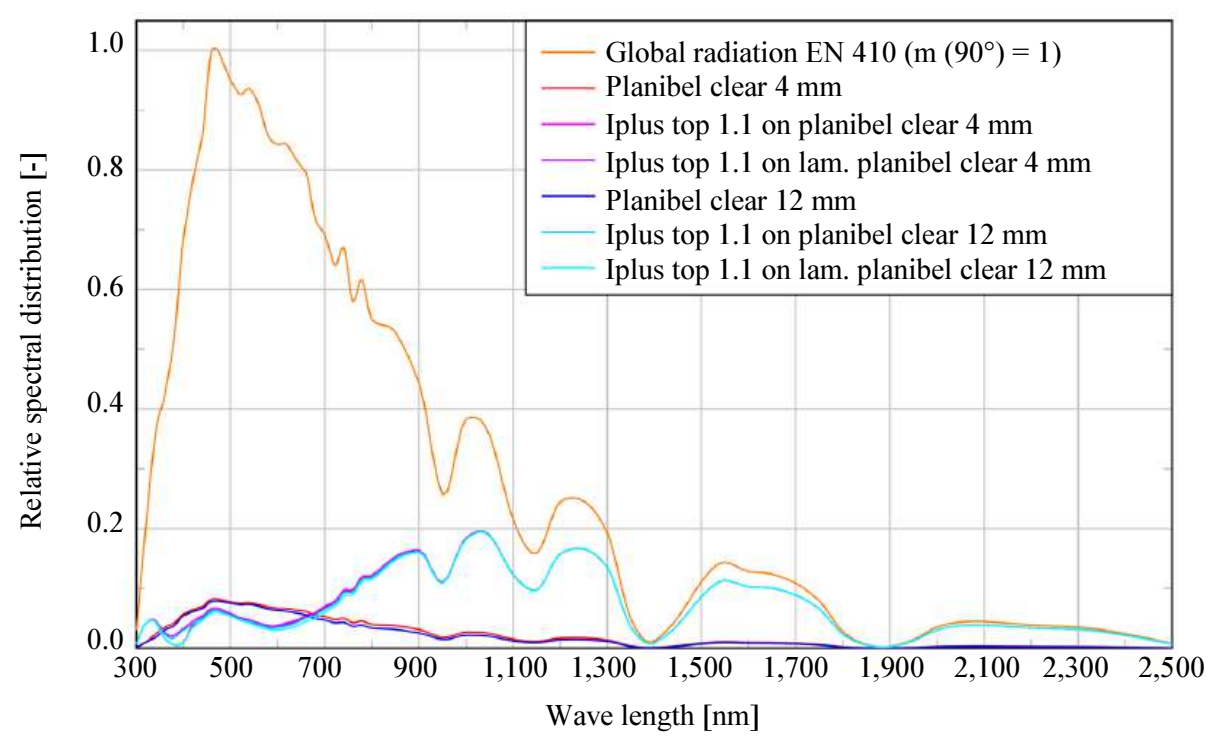

Fig. 6: Solar reflection of low-e coated side (in case of coating) of different glass plates by Interpane (Häuser, 2014)

Table 3: Proposed design values of limiting combinations for effect of actions with bomb blast action on glass plates

\begin{tabular}{lllll}
\hline Combination of actions $\mathrm{E}_{\mathrm{d}}$ & Permanent action & $\begin{array}{l}\text { Accidental action } \\
\text { (blast pressure) }\end{array}$ & $\begin{array}{l}\text { Variable action } \\
\text { (outdoor air temp.) }\end{array}$ & $\begin{array}{l}\text { Variable action } \\
\text { (global radiation) }\end{array}$ \\
\hline $\begin{array}{l}\text { Summer combination } \\
\text { Winter combination }\end{array}$ & $\mathrm{G}_{k, \mathrm{j}}$ & $\mathrm{A}_{\mathrm{d}}$ & $\psi_{1,1} \mathrm{Q}_{k, 1}$ & $\psi_{1,1} \mathrm{Q}_{k, 1}$ \\
\hline
\end{tabular}

Table 4: Proposed design values for variable action with bomb blast action on glass plates for Germany

\begin{tabular}{llll}
\hline Combination of action & Operative room temperature & Outdoor air temperature & Global radiation \\
\hline Ed [-] & {$\left[{ }^{\circ} \mathrm{C}\right]$} & $\psi_{1,1} \mathrm{Q}_{k, 1}\left[{ }^{\circ} \mathrm{C}\right]$ & $\psi_{1,1} \mathrm{Q}_{k, 1}\left[\mathrm{~W} / \mathrm{m}^{2}\right]$ \\
\hline Summer combination (max. interlayer temperature) & 26 (Freiburg) & 25 (Freiburg) & 850 \\
Winter combination (min. interlayer temperature) & 16 (all sites) & -8 (Potsdam) & 0 \\
\hline
\end{tabular}

Table 5: Resulting temperature distribution of investigated double and triple glazed units with boundary conditions shown in Fig. 4

\begin{tabular}{|c|c|c|c|c|c|c|c|c|c|c|}
\hline \multirow{2}{*}{$\begin{array}{l}\text { Glass type } \\
{[-]}\end{array}$} & \multirow{2}{*}{$\begin{array}{l}\text { Combination of } \\
\text { actions } E_{d}[-]\end{array}$} & \multicolumn{7}{|c|}{ Temperature on position i } & \multicolumn{2}{|c|}{ CEN conditions } \\
\hline & & $1\left[{ }^{\circ} \mathrm{C}\right]$ & $2\left[{ }^{\circ} \mathrm{C}\right]$ & $3\left[{ }^{\circ} \mathrm{C}\right]$ & $4\left[{ }^{\circ} \mathrm{C}\right]$ & $5\left[{ }^{\circ} \mathrm{C}\right]$ & $6\left[{ }^{\circ} \mathrm{C}\right]$ & $7\left[{ }^{\circ} \mathrm{C}\right]$ & $\mathrm{U}_{\mathrm{g}}\left[\mathrm{W} /\left(\mathrm{m}^{2} \mathrm{~K}\right)\right]$ & $\mathrm{G}[-]$ \\
\hline \multirow[t]{2}{*}{ DGU 4} & Winter & -6.9 & -6.8 & 13.1 & 13.3 & 13.5 & - & - & 1.11 & 0.62 \\
\hline & Summer & 32.8 & 33.0 & 36.9 & 37.0 & 36.2 & - & - & & \\
\hline \multirow[t]{2}{*}{ DGU 12} & Winter & -7.0 & -6.6 & 12.7 & 13.1 & 13.6 & - & - & 1.07 & 0.55 \\
\hline & Summer & 41.9 & 43.3 & 42.8 & 42.8 & 40.0 & - & - & & \\
\hline \multirow[t]{2}{*}{ TGU 4} & Winter & -7.4 & -7.3 & 3.7 & 3.8 & 14.4 & 14.5 & 14.6 & 0.72 & 0.51 \\
\hline & Summer & 38.0 & 38.4 & 50.9 & 50.9 & 35.9 & 35.8 & 35.1 & & \\
\hline \multirow[t]{2}{*}{ TGU 12} & Winter & -7.4 & -7.2 & 3.6 & 3.7 & 14.1 & 14.3 & 14.6 & 0.70 & 0.46 \\
\hline & Summer & 45.9 & 47.8 & 54.2 & 54.2 & 40.4 & 40.0 & 37.7 & & \\
\hline
\end{tabular}

Table 6: Heat transfer coefficients and heat transfer resistance values for vertical surface according to DIN EN 673 (2011) and DIN EN ISO $6946(2008)$

\begin{tabular}{|c|c|c|c|c|c|}
\hline & $\begin{array}{l}\text { Air temp. } \\
{\left[{ }^{\circ} \mathrm{C}\right]}\end{array}$ & $\begin{array}{l}\text { Heat transfer coefficient } \\
\text { due to convection } \\
\mathrm{h}_{\mathrm{c}}\left[\mathrm{W} /\left(\mathrm{m}^{2} \mathrm{~K}\right)\right]\end{array}$ & $\begin{array}{l}\text { Heat transfer coefficient } \\
\text { due to radiation }{ }^{\text {a) }} \\
\mathrm{h}_{\mathrm{r}}\left[\mathrm{W} /\left(\mathrm{m}^{2} \mathrm{~K}\right)\right]\end{array}$ & $\begin{array}{l}\text { Total heat transfer } \\
\text { coefficient } \\
\mathrm{h}_{\mathrm{c}}+\mathrm{h}_{\mathrm{r}}\left[\mathrm{W} /\left(\mathrm{m}^{2} \mathrm{~K}\right)\right]\end{array}$ & $\begin{array}{l}\text { Total heat transfer } \\
\text { resistance } \\
\mathrm{R}_{\mathrm{si}} \text { or } \mathrm{R}_{\mathrm{se}}\left[\mathrm{m}^{2} \mathrm{~K} / \mathrm{W}\right]\end{array}$ \\
\hline Internal (673) & - & 3.6 & 4.1 & 7.7 & 0.13 \\
\hline \multirow[t]{2}{*}{ Internal (6946) } & 16 & 2.5 & 4.6 & 7.1 & 0.14 \\
\hline & 26 & 2.5 & 5.1 & 7.6 & 0.13 \\
\hline Internal (673) & - & - & - & 25.0 & 0.04 \\
\hline External $4 \mathrm{~m} / \mathrm{s}$ wind & -8 & 20.0 & 3.5 & 23.5 & 0.04 \\
\hline speed (6946) & 25 & 20.0 & 5.0 & 25.0 & 0.04 \\
\hline External $0 \mathrm{~m} / \mathrm{s}$ wind & -8 & 4.0 & 3.5 & 7.5 & 0.13 \\
\hline speed (6946) & 25 & 4.0 & 5.0 & 9.0 & 0.11 \\
\hline
\end{tabular}

a. Air temperature instead of surface temperature is used for calculation 


\section{Laminated Glass Plates Subjected to Blast and Temperature Load}

Within this section, a transient parametric FE study is examined to analyze the influence of interlayer temperatures on laminated glass plates subjected to common idealized blast loads. Therefore, the following system is investigated: Square plate with total thickness $t=13.52 \mathrm{~mm}$ (Fig. 7a and 7c), plate dimensions $b=$ $0.75 \mathrm{~m}, 1 \mathrm{~m}$ and $2 \mathrm{~m}$ and blast load GSA C, EXV45, EXV33, SB1 and GSA D (Fig. 7b and 7d). The blast load is in accordance with Wellershoff et al. (2012, originally in US GSA, 2001) and ISO 16933 (2007(E)). In difference to previous section, laminated glass instead of DGU and TGU is considered for the further study. Hence, the variation of interlayer property can be clearly identified, as no dynamic coupling effects between different glass packages interfere because stiffness variation of laminated glass package in DGU leads to stiffness variation of the Multi Degree Of Freedom (MDOF) system consisting of two masses

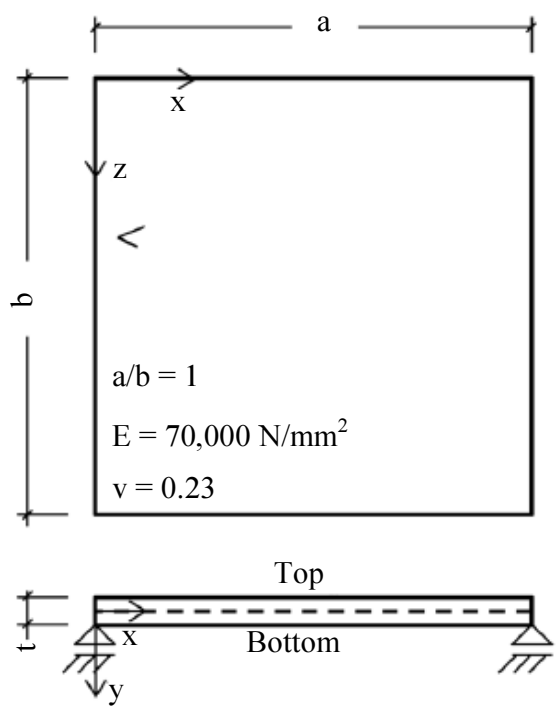

(a)
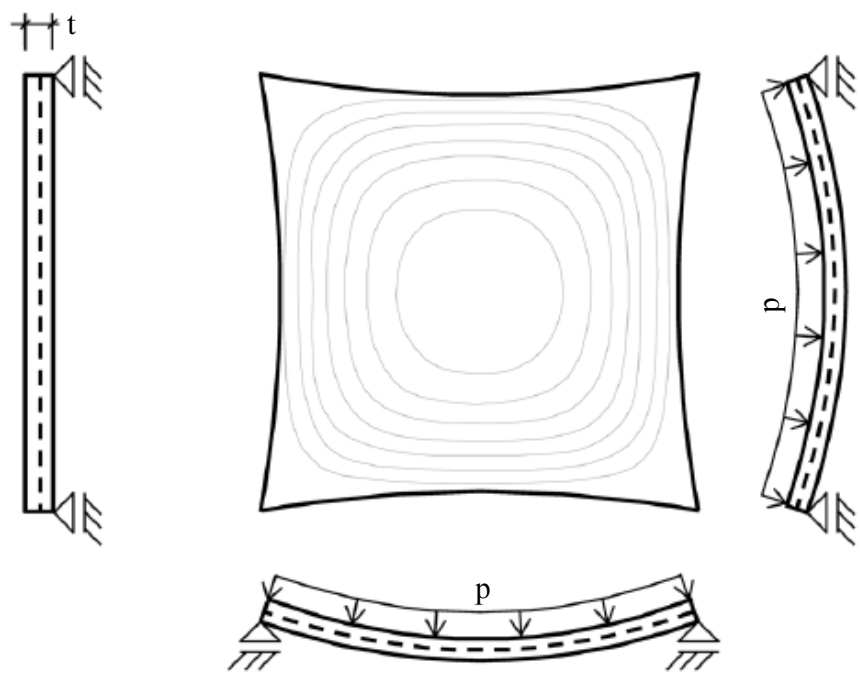

- Monolithic glass

- Laminated glass with interlayer material Saflex PVB

- Laminated glass with interlayer material SGP Ionoplast

The transient mechanical interlayer material behavior for the FE study is considered by generalized Maxwell models according to Fig. 8. Beside the two proposed interlayer temperatures, a room temperature level of $20^{\circ} \mathrm{C}$ is included for comparison reasons. In summary, the following temperatures are analyzed:

- $10^{\circ} \mathrm{C}$ (minimum design interlayer temperature for blast design situation)

- $20^{\circ} \mathrm{C}$ (room temperature)

- $45^{\circ} \mathrm{C}$ (maximum design interlayer temperature for blast design situation)

(b)

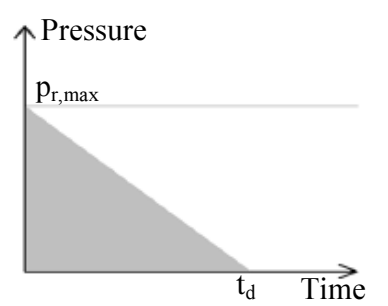

(d)

Fig. 7: Overview of parametric FE study. (a) Undeformed plate with parameters. (b) Deformed plate with load normal to surface. (c) Glass build-up. (d) Idealized time-pressure history for blast load 


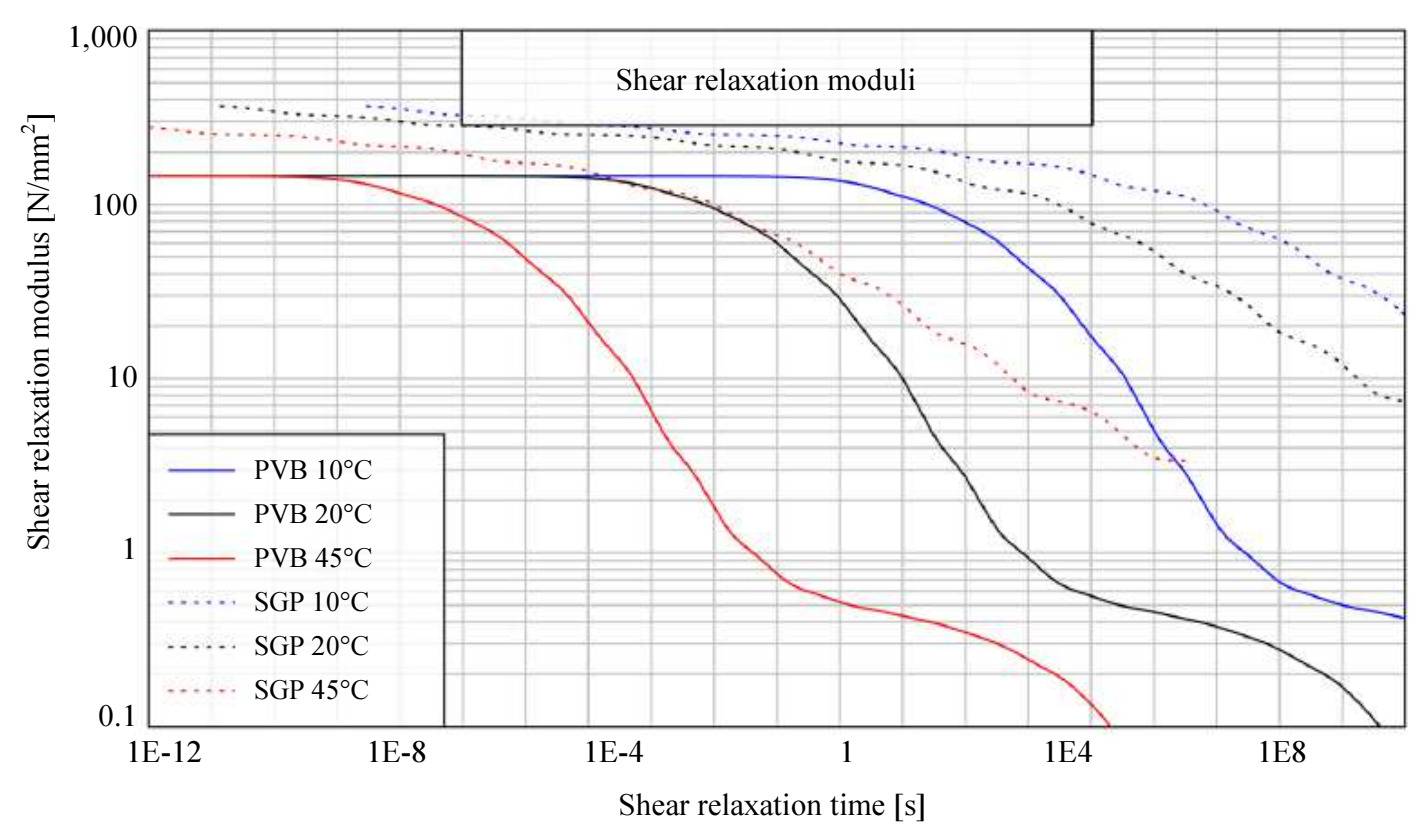

Fig. 8: Shear relaxation curves of Saflex PVB by Solutia Inc. (D’Haene and Savineau, 2007) and SGP Ionoplast De Vogel (2008), originally in Bennison and Gizzi (2007)

Table 7: Result of parametric study (corresponding to Fig. 9)

\begin{tabular}{|c|c|c|c|c|c|}
\hline & GSA C & EXV45 & EXV33 & SB1 & GSA D \\
\hline$\overline{p_{r}, \max }\left[\mathrm{kN} / \mathrm{m}^{2}\right]$ & 27.58 & 30 & 50 & 70 & 68.95 \\
\hline $\mathrm{t}_{\mathrm{d}}[\mathrm{ms}]$ & 14 & 12 & 10 & 4.29 & 19.6 \\
\hline $\mathrm{I}_{\mathrm{r}} / \mathrm{A}[\mathrm{kNms}]$ & 193.06 & 180 & 250 & 150.15 & 675.71 \\
\hline $\mathrm{b}[\mathrm{m}]$ & 2 & 2 & 1 & 2 & 0.75 \\
\hline$\sigma_{\text {max,pr,mono }}\left[\mathrm{N} / \mathrm{mm}^{2}\right]$ & 121.2 & 115.1 & 116.7 & 111.9 & 120.6 \\
\hline$\sigma_{\max , \mathrm{pr}, \mathrm{PVB}, 10^{\circ} \mathrm{C}}\left[\mathrm{N} / \mathrm{mm}^{2}\right]$ & 115.0 & 109.5 & 125.1 & 125.2 & 131.7 \\
\hline 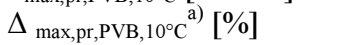 & -5.1 & -4.9 & +7.2 & +11.9 & +9.2 \\
\hline$\sigma_{\max , \mathrm{pr}, \mathrm{PVB}, 20^{\circ} \mathrm{C}}\left[\mathrm{N} / \mathrm{mm}^{2}\right]$ & 116.0 & 111.0 & 121.0 & 125.0 & 129.4 \\
\hline$\Delta_{\max , \operatorname{pr}, \mathrm{PVB}, 20^{\circ} \mathrm{C}}{ }^{a}[\%]$ & -4.3 & -3.6 & +3.7 & +11.7 & +7.3 \\
\hline$\sigma_{\max , p r, P V B, 45^{\circ} \mathrm{C}}\left[\mathrm{N} / \mathrm{mm}^{2}\right]$ & 184.1 & 172.6 & 121.2 & 141.5 & 138.1 \\
\hline$\left.\Delta_{\max , p r, P V B}, 45^{\circ} \mathrm{C}^{a}\right)[\%]$ & +51.9 & +50.0 & +3.9 & +26.5 & +14.5 \\
\hline$\sigma_{\max , \mathrm{pr}, \mathrm{SGP}, 10^{\circ} \mathrm{C}}\left[\mathrm{N} / \mathrm{mm}^{2}\right]$ & 116.0 & 111.1 & 122.8 & 117.4 & 126.6 \\
\hline$\Delta_{\max , \mathrm{pr}, \mathrm{SGP}, 10^{\circ} \mathrm{C}}{ }^{\mathrm{a})}[\%]$ & -4.3 & -3.5 & +5.2 & +4.9 & +5.0 \\
\hline$\sigma_{\max , \mathrm{pr}, \mathrm{SGP}, 20^{\circ} \mathrm{C}}\left[\mathrm{N} / \mathrm{mm}^{2}\right]$ & 115.9 & 111.0 & 123.0 & 118.3 & 127.5 \\
\hline$\Delta_{\max , \mathrm{pr}, \mathrm{SGP}, 20^{\circ} \mathrm{C}}{ }^{\mathrm{a})}[\%]$ & -4.4 & -3.6 & +5.4 & +5.7 & +5.7 \\
\hline$\sigma_{\max , \mathrm{pr}, \mathrm{SGP}, 45^{\circ} \mathrm{C}}\left[\mathrm{N} / \mathrm{mm}^{2}\right]$ & 115.9 & 111.0 & 121.5 & 124.8 & 129.8 \\
\hline$\Delta_{\max , \mathrm{pr}, \mathrm{SGP}, 45^{\circ} \mathrm{C}^{\mathrm{a})}}[\%]$ & -4.4 & -3.6 & +4.1 & +11.5 & +7.6 \\
\hline Position of $\sigma_{\max , p r, m o n o}$ & $\mathrm{Co}^{\mathrm{b})} 1^{\mathrm{c})} \mathrm{B}^{\mathrm{d})}$ & $\mathrm{Co}^{\mathrm{b})} 1^{\mathrm{c})} \mathrm{B}^{\mathrm{d})}$ & $\mathrm{Ce}^{\mathrm{b})} 1^{\mathrm{c})} \mathrm{B}^{\mathrm{d})}$ & $\mathrm{Ce}^{\mathrm{b})} 1^{\mathrm{c})} \mathrm{B}^{\mathrm{d})}$ & $\mathrm{Ce}^{\mathrm{b})} 1^{\mathrm{c})} \mathrm{B}^{\mathrm{d})}$ \\
\hline Position of $\sigma_{\max , p r}$ PVB, $10^{\circ} \mathrm{C}$ & $A^{\text {b) }} 1^{c)} B^{d)}$ & $A^{\text {b) }} 1^{c)} B^{d)}$ & $C e^{b)} 1^{c)} B^{d)}$ & $\mathrm{Ce}^{\mathrm{b})} 1^{\mathrm{c})} \mathrm{B}^{\mathrm{d})}$ & $\mathrm{Ce}^{\mathrm{b})} 1^{\mathrm{c})} \mathrm{B}^{\mathrm{d})}$ \\
\hline Position of $\sigma_{\max , \mathrm{pr}, \mathrm{PVB}, 20^{\circ} \mathrm{C}}$ & $A^{b)} 1^{c)} B^{d)}$ & $A^{b)} 1^{c)} B^{d)}$ & $C e^{b)} 1^{c)} B^{d)}$ & $\mathrm{Ce}^{\mathrm{b})} 1^{\mathrm{c})} \mathrm{B}^{\mathrm{d})}$ & $\mathrm{Ce}^{\mathrm{b})} 1^{\mathrm{c})} \mathrm{B}^{\mathrm{d})}$ \\
\hline Position of $\sigma_{\max , p r, P V B, 45^{\circ} \mathrm{C}}$ & $\mathrm{Co}^{\mathrm{b})} 1^{\mathrm{c})} \mathrm{T}^{\mathrm{d})}$ & $\mathrm{Co}^{\mathrm{b})} 1^{\mathrm{c})} \mathrm{T}^{\mathrm{d})}$ & $C e^{b)} 1^{c)} B^{d)}$ & $\mathrm{Ce}^{\mathrm{b})} 1^{\mathrm{c})} \mathrm{B}^{\mathrm{d})}$ & $\mathrm{Ce}^{\mathrm{b})} 1^{\mathrm{c})} \mathrm{B}^{\mathrm{d})}$ \\
\hline Position of $\sigma_{\max , p r}, \mathrm{SGP}, 10^{\circ} \mathrm{C}$ & $A^{b)} 1^{c)} B^{d)}$ & $\mathrm{A}^{\mathrm{b})} 1^{\mathrm{c})} \mathrm{B}^{\mathrm{d})}$ & $C e^{b)} 1^{c)} B^{d)}$ & $\mathrm{Ce}^{\mathrm{b})} 1^{\mathrm{c})} \mathrm{B}^{\mathrm{d})}$ & $\mathrm{Ce}^{\mathrm{b})} 1^{\mathrm{c})} \mathrm{B}^{\mathrm{d})}$ \\
\hline Position of $\sigma_{\max , \mathrm{pr}} \mathrm{SGP}, 20^{\circ} \mathrm{C}$ & $A^{b)} 1^{c)} B^{d)}$ & $A^{b)} 1^{c)} B^{d)}$ & $\mathrm{Ce}^{\mathrm{b})} 1^{\mathrm{c})} \mathrm{B}^{\mathrm{d})}$ & $\mathrm{Ce}^{\mathrm{b})} 1^{\mathrm{c})} \mathrm{B}^{\mathrm{d})}$ & $\mathrm{Ce}^{\mathrm{b})} 1^{\mathrm{c})} \mathrm{B}^{\mathrm{d})}$ \\
\hline Position of $\sigma_{\max , \mathrm{pr}, \mathrm{SGP}, 45^{\circ} \mathrm{C}}$ & $\mathrm{A}^{\mathrm{b})} 1^{\mathrm{c})} \mathrm{B}^{\mathrm{d})}$ & $A^{b)} 1^{c)} B^{d)}$ & $\mathrm{Ce}^{\mathrm{b})} 1^{\mathrm{c})} \mathrm{B}^{\mathrm{d})}$ & $\mathrm{Ce}^{\mathrm{b})} 1^{\mathrm{c})} \mathrm{B}^{\mathrm{d})}$ & $\mathrm{Ce}^{\mathrm{b})} 1^{\mathrm{c})} \mathrm{B}^{\mathrm{d})}$ \\
\hline
\end{tabular}

a. Difference in comparison to monolithic glass; b. Corner (Co), Center (Ce) or Transition area between corner and center (A); $\mathrm{c}$. Layer 1 (1) according to Fig. 7c; d. Bottom side of layer (B) or Top side of layer (T) according to Fig. 7c

The conducted transient FE calculations are performed in Ansys (2014) with geometrical nonlinear approach, considering the first amplitude of the vibrating plate. The boundary conditions and pressure application of the structural model with line supports in positive and negative y-direction are shown in Figure 7. For analysis, 
a quarter plate model consisting of 20-node solid elements (solid186) is used. The mesh size is presented in Fig. 10 and defined as 80 elements equally distributed over plate dimension $b$, with corner refinement using half element size. For some PVB calculations at $45^{\circ} \mathrm{C}$ temperature level a refined corner mesh is used. Two solid elements over each glass layer thickness (Fig. 7c) and 4 solid elements over interlayer thickness are modeled. Dimension $b$ and blast load are selected with respect to monolithic fully tempered glass, so that the maximum principal stress is below the design strength of $122.6 \mathrm{~N} / \mathrm{mm}^{2}$ for $t_{f} \leq 8 \mathrm{~ms}$ that is applicable for all investigated systems. The design strength refers to a characteristic bending strength $f_{k}$ of $120 \mathrm{~N} / \mathrm{mm}^{2}$, a load duration factor $k_{m o d}$ of 1.12 and a partial factor $\gamma_{M}$ of 1.1 presented in Förch (2019) on the basis of detailed experimental investigations. Figure 9 presents the result of the parametric study, by comparing maximum principal stress of monolithic glass with laminated glass for 3 temperature levels. A detailed summary is contained in Table 7. As a result, the laminated glass system shows a maximum principal stress increase in comparison to monolithic glass of:

- Up to $52 \%$ for PVB interlayer at $45^{\circ} \mathrm{C}$

- Up to $12 \%$ for PVB interlayer at $10^{\circ} \mathrm{C}$ and $20^{\circ} \mathrm{C}$

- Up to $12 \%$ for SGP interlayer at $45^{\circ} \mathrm{C}$

- Up to $6 \%$ for SGP interlayer at $10^{\circ} \mathrm{C}$ and $20^{\circ} \mathrm{C}$

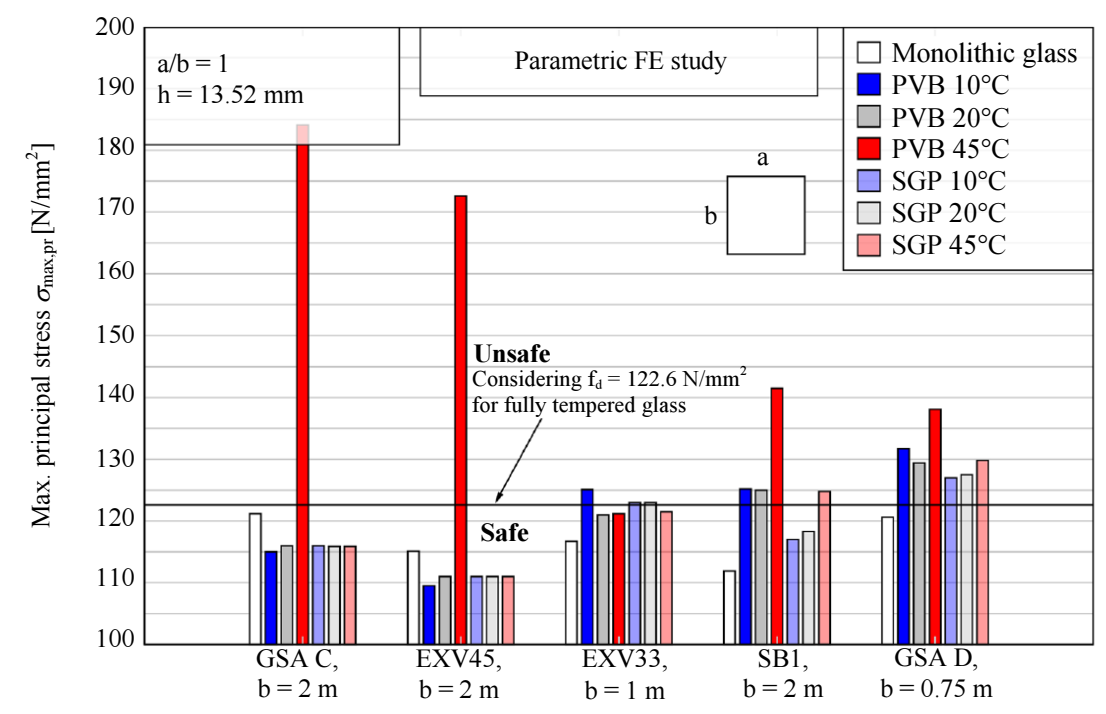

Fig. 9: Maximum principal stresses of monolithic glass in comparison to laminated glass for three temperature levels. Interlayer type PVB and SGP according to Fig. 8

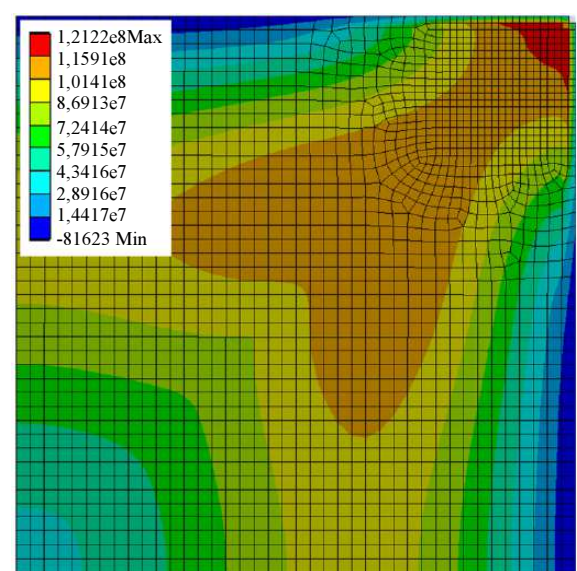

(a)

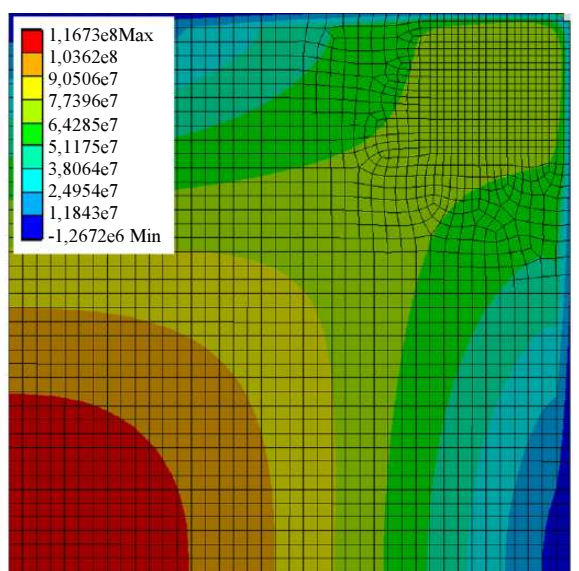

(b)

Fig. 10: Mesh size of quarter plate model with corner refinement (Bottom view, Layer 1). (a) Maximum principal stress in Pa for monolithic glass under GSA C load at time $14.63 \mathrm{~ms}$. (b) Maximum principal stress in Pa for monolithic glass under EXV33 load at time $6.096 \mathrm{~ms}$. Corner element is not displayed due to stress singularity 
Under these circumstances, many laminated glass systems turn to unsafe, whereas a consideration as monolithic glass would be safe. In general, a deformation increase between $4 \%$ and $175 \%$ is observed for all laminated glass systems in comparison to monolithic glass. Because of this, a decrease of maximum principal stress $\sigma_{\text {max, } p r}$ up to $-5 \%$ is found for systems with maximum principal stress of monolithic glass in corner position, as $\sigma_{\max , p r}$ of monolithic glass in corner position moves in transition area between corner and center for laminated glass (cf. Fig. 10).

\section{Conclusion}

This article presents detailed investigation of timetemperature dependency for laminated glass subjected to blast load. Main focus is to develop an understanding of interlayer temperature dependency under very short loading and whether the laminate may be regarded as monolithic cross section for simplification.

First, a brief introduction to the mechanical behavior of interlayers is provided, showing that the mechanical behavior of interlayer materials strongly depends on interlayer temperature and shear relaxation time.

Second, the design temperature of interlayer in blast design situation for vertical double glazed and triple glazed units is determined for Germany. Therefore, maximum outdoor air temperature and maximum global radiation from 7 weather stations for a 50 year period are surveyed, in order to define a design interlayer temperature for blast design situation according to Eurocode 0 . Hence a summer combination for maximum interlayer temperature and a winter combination for minimum interlayer temperature are used for steady-state thermal calculations, resulting in a minimum design interlayer temperature of $13.1^{\circ} \mathrm{C}$ and a maximum design interlayer temperature of $42.8^{\circ} \mathrm{C}$. Accordingly, two interlayer temperatures are proposed to be considered for blast design situation in Germany: $10^{\circ} \mathrm{C}$ as minimum design interlayer temperature for blast design situation and $45^{\circ} \mathrm{C}$ as maximum design interlayer temperature for blast design situation.

Third, laminated glass plates subjected to common idealized blast loads are analyzed for the two proposed interlayer temperatures by transient FEA. Under these conditions, a parametric study for quadratic laminated glass plates with total thickness $13.52 \mathrm{~mm}$, consisting of $6 \mathrm{~mm}$ glass, $1.52 \mathrm{~mm}$ interlayer and $6 \mathrm{~mm}$ glass, is done. Idealized blast loads, interlayer materials and plate widths are varied.

Although only analyzing one glass thickness and plate ratio, the following indication for common idealized blast loads is observed: Laminated glass should be regarded with appropriate shear relaxation modulus for interlayers, as maximum principal stresses may be up to $12 \%$ higher in comparison with monolithic glass, while investigating at minimum design interlayer temperature of $10^{\circ} \mathrm{C}$ and maximum principal stresses may be up to $52 \%$ higher in comparison with monolithic glass while investigating at maximum design interlayer temperature of $45^{\circ} \mathrm{C}$. A maximum deformation increase up to $175 \%$ is observed for laminated glass in comparison to monolithic glass.

As a result, laminated glass subjected to blast load in combination with temperature exposure should be regarded with appropriate shear relaxation moduli for interlayers as simplification to monolithic glass may turn to unsafe condition.

\section{Acknowledgement}

I would like to thank my academic supervisor Prof. Dr.-Ing. Frank Wellershoff for giving me the opportunity to join his team as research associate. The author greatly acknowledges the support of Interpane for providing spectral data for different glass products and the permission for publication.

\section{Ethics}

The content of this paper is part of the doctoral dissertation Förch (2019) at HafenCity University Hamburg. The Author confirms that there is no conflict of interest.

\section{References}

Ansys, 2014. Mechanical products version 15.0. Canonsburg, Pa.

Bennison, S.J., A. Jagota and A. Smith, 1999. Fracture of glass/poly(vinyl butyral) (Butacite $\AA$ ) laminates in biaxial flexure. J. Am. Ceramic Society, 82: 1761-1770.

DOI: 10.1111/j.1151-2916.1999.tb01997.x

Bennison, S.J. and V. Gizzi, 2007. Structural properties of laminated glass. Glass Perfomance Days, Tampere (not published).

Bermbach, T., M. Teich and N. Gebbeken, 2016. Experimental investigation of energy dissipation mechanisms in laminated safety glass for combined blast-temperature loading scenarios. Glass Structures Eng., 1: 331-350. DOI: 10.1007/s40940-016-0029-y

D'Haene, P. and G. Savineau, 2007. Mechanical properties of laminated safety glass-FEM Study. Proceedings of the Glass Performance Days, (GPD' 07), pp: 594-598.

De Vogel, K., 2008. Torsiestijfheid van glas/ionomeer laminaten in functie van temperatuur en belastingsduur. MSc Thesis, Ghent University. 
Del Linz, P., 2014. Blast Resistance of Laminated Glass Facades. 1st Edn., Doctoral Dissertation, Imperial College London.

Deutscher Wetterdienst, 2014. Observed meteorological data from weather stations Braunschweig. Freiburg, Norderney, Potsdam, Trier-Petrisberg, WeihenstephanDürnast and Würzburg between 1964 and 2013.

DIN EN 12898, 2001. Glass in building. Determination of the emissivity. German version EN 12898:2001. Beuth, Berlin. DOI: 10.31030/9124452

DIN EN ISO 6946, 2008. Building components and building elements. Thermal resistance and thermal transmittance. Calculation method (ISO 6946:2007). German version EN ISO 6946:2007. Beuth, Berlin.

DIN EN 1990, 2010. Eurocode: Basis of structural design. German version EN 1990:2002 + A1:2005+A1:2005/AC:2010. Beuth, Berlin.

DIN EN 1990/NA, 2010. National annex. Nationally determined parameters. Eurocode: Basis of structural design. Beuth, Berlin.

DIN EN 1991-1-5, 2010. Eurocode 1. Actions on structures Part 1-5: General actions. Thermal actions. German version EN 1991-1-5: 2003+AC:2009. Beuth, Berlin.

DIN EN 1991-1-5/NA, 2010. National annex. Nationally determined parameters. Eurocode 1: Actions on structures Part 1-5: General actions. Thermalactions. Beuth, Berlin.

DIN EN 410, 2011. Glass in building. Determination of luminous and solar characteristics of glazing. German version EN 410: 2011. Beuth, Berlin.

DIN EN 673, 2011. Glass in building. Determination of thermal transmittance (U value). Calculation method. German version EN 673:2011. Beuth, Berlin.

DIN EN 15251, 2012. Indoor environmental input parameters for design and assessment of energy performance of buildings addressing indoor air quality, thermal environment, lighting and acoustics. German version EN 15251:2007. Beuth, Berlin.

DIN EN 1990/NA/A1, 2012. National annex. Nationally determined parameters. Eurocode: Basis of structural design. Amendment A1. Beuth, Berlin.

Förch, M., 2019. Analysis of Glass Panels Subjected to Blast Load. 1st Edn., Springer, Berlin. DOI:10.1007/978-3-662-59087-4.

GeoBasis-DE/BKG, 2018. Digital Germany map, currentness.

Gulvanessian, H., J.A. Calgaro and M. Holický, 2012. Designers' guide to eurocode: Basis of structural design EN1990. ICE Publishing, London.

Häuser, K., 2014. Laboratory spectral data report of glass products (not published).

Hooper, P., 2001. Blast Performance of Silicone-Bonded Laminated Glass. 1st Edn., Imperial College London.
ISO 16933, 2007. Glass in building. Explosionresistant security glazing. Test and classification for arena air-blast loading. International standard, Geneva.

Kolling, S., J. Schneider, N. Gebbeken, M. Larcher and C. Alter et al., 2012. Deformations- und Bruchverhalten von Verbundsicherheitsglas unter dynamischer Beanspruchung. Stahlbau, 81: 219225. DOI: $10.1002 /$ stab.201201536

Kuntsche, J., 2015. Mechanical Behaviour of Laminated Glass Under Time-Dependent and Explosion Loading (in German). 1st Edn., Springer, Berlin, ISBN-10: 3662488302. pp: 254.

Kutterer, M., 2003. Verbundglasplatten. 1st Edn., Shaker Verlag, Herzogenrath, ISBN-10: 3832215069, pp: 132.

Makki, E.A., P.N. Parrikar and A. Shukla, 2015. Response of coated laminated glass panels subjected to combined blast and temperature loadings. J. Dynamic Behav. Mater., 4: 409-422.

DOI: $10.1007 / \mathrm{s} 40870-015-0036-0$

Palz, W. and J. Greif, 1996. European Solar Radiation Atlas. In: Solar Radiation on Horizontal and Inclined Surfaces, Palz, W. and J. Greif (Eds.), Springer, Berlin, ISBN-10: 978-3-642-80239-3.

Sackmann, V., 2008. Untersuchungen zur Dauerhaftigkeit des Schubverbunds in Verbundsicherheitsglas mit unterschiedlichen Folien aus Polyvinylbutyral. Doctoral Dissertation, Technische Universität München, München.

Schuler, C., 2003. Einfluss Des Materialverhaltens von Polyvinylbutyral auf das Tragverhalten von Verbundsicherheitsglas in Abhängigkeit von Temperatur und Belastung. Doctoral dissertation, Technische Universität München, München.

US GSA, 2001. General services administration. security design criteria. General Services Administration (GSA), Interagency Security Committee (ISC) (for official use only).

Vallabhan, C.V., M. Magdi, M. Asik and J.R. Bailey, 1993. Analysis of laminated glass units. J. Structural Eng., 119: 1572-1585.

DOI: 10.1061/(ASCE)0733-9445(1993)119:5(1572)

Van Dijk, D., L. Bakker, L. Soethout and R. Versluis, 2006. WIS software. Version 3.0.1 SP 2.

Van Duser, A., A. Jagota and S.J. Bennison, 1999. Analysis of glass/polyvinyl butyral laminates subjected to uniform pressure. J. Eng. Mech., 125: 435-442.

DOI: 10.1061/(ASCE)0733-9399(1999)125:4(435)

VDI 3789, 1994. Part 2: Environmental meteorology. Interactions between atmosphere and surfaces. Calculation of short-wave and long-wave radiation. Verein Deutscher Ingenieure, Düsseldorf. 
VDI 3789, 2001. Part 3: Environmental meteorology. Interactions between atmosphere and surfaces. Calculation of spectral irradiances in the solar wavelength range. Verein Deutscher Ingenieure, Düsseldorf.

Wei, J. and L.R. Dharani, 2005. Fracture mechanics of laminated glass subjected to blast loading. Theoret. Applied Fracture Mech., 44: 157-167.

DOI: $10.1016 /$ j.tafmec.2005.06.004
Wellershoff, F., 2006. Nutzung der Verglasung zur Aussteifung von Gebäudehüllen. Stahlbau, 75: 677-677. DOI: 10.1002/stab.200690093

Wellershoff, F., M. Teich, G. Nehring and N. Gebbeken, 2012. Konstruktion und Berechnung von explosionshemmenden Seilnetzfassaden. Stahlbau, 81: 13-25. DOI: 10.1002/stab.201201501 